\title{
Do trials that report a neutral or negative treatment effect improve the care of critically ill patients? Yes
}

\author{
Anders Perner ${ }^{1 *}(1)$ and Simon Finfer ${ }^{2}$ (B)
}

(C) 2018 Springer-Verlag GmbH Germany, part of Springer Nature and ESICM

\section{Introduction}

Over the last half-century, the emergence and evolution of critical care has made possible the conduct of incredibly complex lifesaving surgery and the recovery of untold thousands of critically ill medical patients who previously had no chance of survival [1]. Despite this success, most interventions delivered to critically ill patients were adopted based on physiological theory or "borrowed" from other settings, e.g., positive pressure ventilation from the operating room and fluid resuscitation from the infirmaries and battlefields of the world wars. While this approach was entirely appropriate in the early days of our specialty, it is now clear that many standard practices of the past, and some new ones, harmed the very patients they were designed to help. We know this predominantly because academic researchers have designed and conducted high-quality, robust, pragmatic randomised clinical trials (RCTs); many of the trials that have improved the care of our patients have reported neutral or negative treatment effects.

\section{Clinical trials in critical care}

The conduct of RCTs in critical care is challenging; patients are rarely able to give or withhold consent, diagnosis may be unclear early in the clinical course, making complex inclusion criteria difficult to apply, interventions are often time-critical, and the natural trajectory

\footnotetext{
*Correspondence: anders.perner@regionh.dk

${ }^{1}$ Department of Intensive Care, Rigshospitalet, University of Copenhagen, Copenhagen, Denmark

Full author information is available at the end of the article
}

For a contrasting viewpoint, please go to https://doi.org/10.1007/s0013 4-018-5220-y. of critical illness is incredibly variable. Although clinical trial methodology is continually evolving with exciting new methods such as adaptive and platform trials being brought to bear [2,3], most high-quality evidence comes from traditional individual or cluster RCTs, which, simplistically, can be divided into efficacy and effectiveness trials [4]. Efficacy trials are designed to answer the question, "Does this intervention work in the ideal patient population in the ideal circumstances?" Efficacy trials typically use complex inclusion and exclusion criteria and are the appropriate design when investigating the likely impact of a new intervention [4]. Efficacy trials sacrifice the ability to apply their results to real-world practice in pursuit of maximal internal validity. In contrast, effectiveness trials, also called pragmatic trials, are designed to determine the effect of an intervention when it is used in more a diverse population or typical clinical settings [5]. Notable features include simplified inclusion and exclusion criteria that seek to maximise generalisability and thus to understand the true impact of new and established treatments on outcomes important to patients [5].

\section{The impact of trials that demonstrate harm}

On this background it is both rational and essential to test as many of the interventions used in critical care as possible. Priority should be given to interventions that are used for to many patients, interventions that are costly or labour intensive and those for which there is insufficient evidence to reliably estimate the balance between benefit and harm. That the risk of us causing harm to our patients is real is confirmed by a recent systematic review that reported on RCTs in critical care in which the intervention studied significantly affected mortality; mortality was increased by half the interventions studied

\section{Springer}




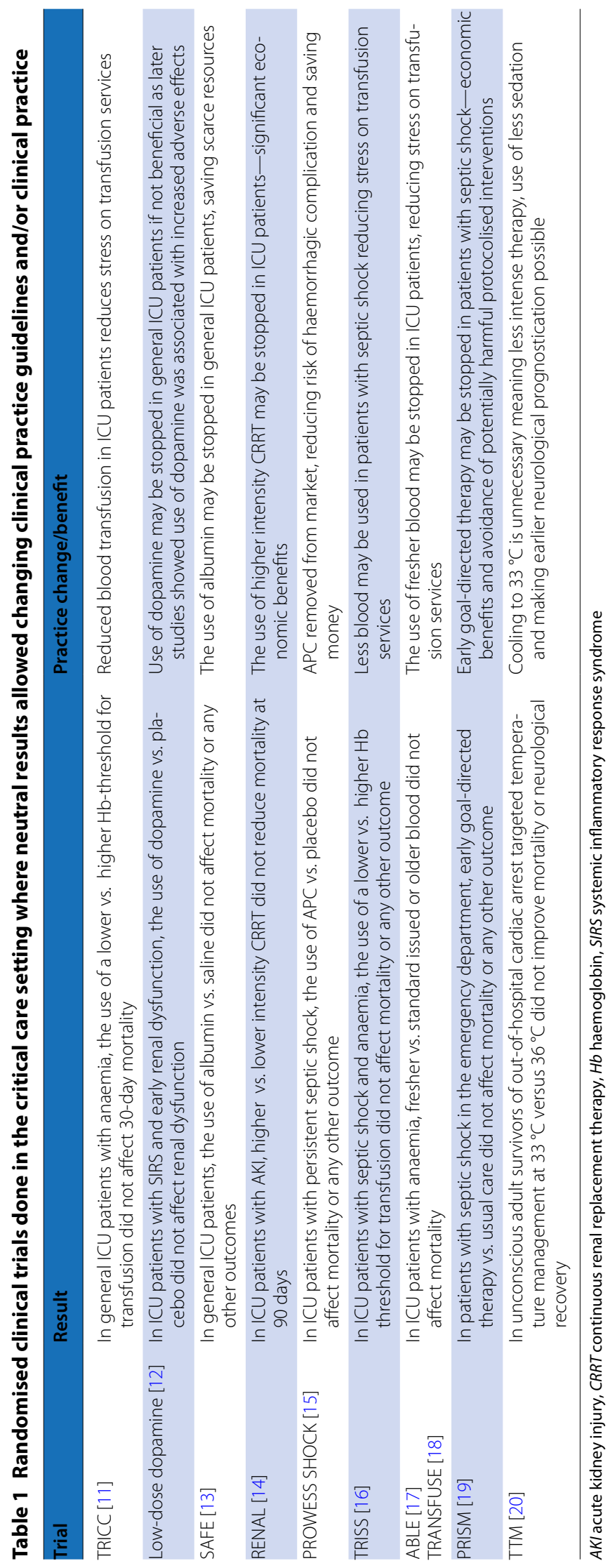


[6]. Notably critical trials that report harm are generally of higher quality, being more likely to be multi-centred and blinded and have larger sample sizes [7]. Importantly, many interventions shown to be harmful in highquality trials were in regular clinical use at the time of testing, including high-frequency oscillatory ventilation [8], hydroxyethyl starch [9] and intensive glucose control [10]. In reaction to these results, clinicians, guideline writers and regulators have taken actions to reduce the use of harmful interventions and thus to improve outcomes for our patients.

\section{The impact of trials that report a neutral treatment effect}

A positive, a neutral and a negative result for a given test of intervention $\mathrm{X}$ vs. intervention $\mathrm{Y}$ will be highly informative for clinicians, those writing clinical practice guidelines and policy-makers and healthcare funders provided the research is of high quality and free from significant risk of bias. The results of robust pragmatic trials allow everyone to change clinical practice with confidence. Some of the many RCTs with neutral results that have allowed us to provide better and more cost-effective care are listed in Table 1.

\section{Simplifying critical care}

Trials reporting neutral or negative treatment effects are important in the process of simplifying critical care as they show us what not to do. As many standard critical care interventions and therapeutic targets are being challenged, simplifying care becomes increasingly rational from the patient, organisational and financial perspective. Doing less may improve patients' outcomes, reduce the number of drug interactions and adverse events and save money. Doing less allows us to focus our efforts on what is important to patients, notably to reduce pain, anxiety, thirst, breathlessness and other distressing symptoms. Additionally, simplification will harmonise care, which will facilitate staff training. Simple care will form a cleaner baseline for observational and interventional research and thereby increase the likelihood of developing new diagnostics, risk scores and interventions that will be useful for future patients.

\section{Summary}

While it is tempting to be disappointed when an RCT reports that a new or established treatment does not have demonstrable beneficial effects, or even harms our patients, such information is critical and has undoubtedly contributed to the improved outcomes now experienced by critically ill patients. We must stop characterising such results as "negative trials" and instead celebrate the knowledge they provide and encourage all critical care practitioners to incorporate that knowledge into their decision making at the bedside.

\section{Author details}

${ }^{1}$ Department of Intensive Care, Rigshospitalet, University of Copenhagen, Copenhagen, Denmark. ${ }^{2}$ Malcolm Fisher Department of Intensive Care Medicine, Royal North Shore Hospital, The George Institute of Global Health, University of New South Wales, Sydney, NSW, Australia.

\section{Compliance with ethical standards}

\section{Conflicts of interest}

AP is member of the steering committee and Danish national investigator of the Sepsis Act vasopressin trial in septic shock sponsored by Ferring Pharmaceuticals; his department is reimbursed for his time. The department also receives research funds from Fresenius Kabi for the EAT-ICU nutrition trial and CSL Behring for the INSTINCT trial on immunoglobulins for NSTI. The George Institute for Global Health, as SF's academic institution, has received research grants and reimbursement of travel expenses and payment for SF's time as a consultant from Baxter Healthcare, Bristol Myers Squibb, CSL Bioplasma and Fresenius Kabi.

Received: 27 February 2018 Accepted: 5 March 2018

Published online: 11 June 2018

\section{References}

1. Finfer S, Vincent $J \mathrm{~L}$ (2013) Critical care-an all-encompassing specialty. N Engl J Med 369:669-670

2. Berry SM, Connor JT, Lewis RJ (2015) The platform trial: an efficient strategy for evaluating multiple treatments. JAMA 313:1619-1620

3. Meurer WJ, Lewis RJ, Berry DA (2012) Adaptive clinical trials: a partial remedy for the therapeutic misconception? JAMA 307:2377-2378

4. Hebert PC, Cook DJ, Wells G, Marshall J (2002) The design of randomized clinical trials in critically ill patients. Chest 121:1290-1300

5. Ware JH, Hamel MB (2011) Pragmatic trials-guides to better patient care? N Engl J Med 364:1685-1687

6. Landoni G, Comis M, Conte M, Finco G, Mucchetti M, Paternoster G, Pisano A, Ruggeri L, Alvaro G, Angelone M, Bergonzi PC, Bocchino S, Borghi G, Bove T, Buscaglia G, Cabrini L, Callegher L, Caramelli F, Colombo S, Corno L, Del Sarto P, Feltracco P, Forti A, Ganzaroli M, Greco M, Guarracino F, Lembo R, Lobreglio R, Meroni R, Monaco F, Musu M, Pala G, Pasin L, Pieri M, Pisarra S, Ponticelli G, Roasio A, Santini F, Silvetti S, Szekely A, Zambon M, Zucchetti MC, Zangrillo A, Bellomo R (2015) Mortality in multicenter critical care trials: an analysis of interventions with a significant effect. Crit Care Med 43:1559-1568

7. Baiardo Redaelli M, Landoni G, Di Sanzo S, Frassoni S, Sartini C, Cabrini L, Monti G, Scandroglio M, Zangrillo A, Bellomo R (2017) Interventions affecting mortality in critically ill and perioperative patients: a systematic review of contemporary trials. J Crit Care 41:107-111

8. Ferguson ND, Cook DJ, Guyatt GH, Mehta S, Hand L, Austin P, Zhou Q, Matte A, Walter SD, Lamontagne F, Granton JT, Arabi YM, Arroliga AC, Stewart TE, Slutsky AS, Meade MO (2013) High-frequency oscillation in early acute respiratory distress syndrome. N Engl J Med 368:795-805

9. Perner A, Haase N, Guttormsen AB, Tenhunen J, Klemenzson G, Àneman A, Madsen KR, Møller MH, Elkjær JM, Poulsen LM, Bendtsen A, Winding R, Steensen M, Berezowicz P, Søe-Jensen P, Bestle M, Strand K, Wiis J, White JO, Thornberg KJ, Quist L, Nielsen J, Andersen LH, Holst LB, Thormar K, Kjældgaard AL, Fabritius ML, Mondrup F, Pott FC, Møller TP, Winkel P, Wetterslev J (2012) Hydroxyethyl starch 130/0.42 versus Ringer's acetate in severe sepsis. N Engl J Med 367:124-134

10. NICE-SUGAR Study Investigators, Finfer S, Chittock DR, Su SY, Blair D, Foster D, Dhingra V, Bellomo R, Cook D, Dodek P, Henderson WR, Hebert PC, Heritier S, Heyland DK, McArthur C, McDonald E, Mitchell I, Myburgh JA, Norton R, Potter J, Robinson BG, Ronco JJ (2009) Intensive versus 
conventional glucose control in critically ill patients. N Engl J Med 360:1283-1297

11. Hebert PC, Wells G, Blajchman MA, Marshall J, Martin C, Pagliarello G, Tweeddale M, Schweitzer I, Yetisir E, Transfusion Requirements in Critical Care Investigators for the Canadian Critical Care Trials Group (1999) A multicenter, randomized, controlled clinical trial of transfusion requirements in critical care. N Engl J Med 340:409-417

12. Bellomo R, Chapman M, Finfer S, Hickling K, Myburgh J, Australian and New Zealand Intensive Care Society (ANZICS) Clinical Trials Group (2000) Low-dose dopamine in patients with early renal dysfunction: a placebocontrolled randomised trial. Lancet 356:2139-2143

13. Finfer S, Bellomo R, Boyce N, French J, Myburgh J, Norton R (2004) A comparison of albumin and saline for fluid resuscitation in the intensive care unit. N Engl J Med 350:2247-2256

14. Bellomo R, Cass A, Cole L, Finfer S, Gallagher M, Lo S, McArthur C, McGuinness S, Myburgh J, Norton R, Scheinkestel C, Su S (2009) Intensity of continuous renal-replacement therapy in critically ill patients. N Engl J Med 361:1627-1638

15. Ranieri VM, Thompson BT, Barie PS, Dhainaut JF, Douglas IS, Finfer S, Gårdlund B, Marshall JC, Rhodes A, Artigas A, Payen D, Tenhunen J, Al-Khalidi HR, Thompson V, Janes J, Macias WL, Vangerow B, Williams MD (2012) Drotrecogin alfa (activated) in adults with septic shock. N Engl J Med 366:2055-2064

16. Holst LB, Haase N, Wetterslev J, Wernerman J, Guttormsen AB, Karlsson S, Johansson PI, Aneman A, Vang ML, Winding R, Nebrich L, Nibro HL, Rasmussen BS, Lauridsen JR, Nielsen JS, Oldner A, Pettila V, Cronhjort MB, Andersen LH, Pedersen UG, Reiter N, Wiis J, White JO, Russell L, Thornberg KJ, Hjortrup PB, Muller RG, Moller MH, Steensen M, Tjader I, Kilsand K,
Odeberg-Wernerman S, Sjobo B, Bundgaard H, Thyo MA, Lodahl D, Maerkedahl R, Albeck C, Illum D, Kruse M, Winkel P, Perner A (2014) Lower versus higher hemoglobin threshold for transfusion in septic shock. N Engl J Med 371:1381-1391

17. Lacroix J, Hebert PC, Fergusson DA, Tinmouth A, Cook DJ, Marshall JC, Clayton L, McIntyre L, Callum J, Turgeon AF, Blajchman MA, Walsh TS, Stanworth SJ, Campbell H, Capellier G, Tiberghien P, Bardiaux L, van de Watering L, van der Meer NJ, Sabri E, Vo D (2015) Age of transfused blood in critically ill adults. N Engl J Med 372:1410-1418

18. Cooper DJ, McQuilten ZK, Nichol A, Ady B, Aubron C, Bailey M, Bellomo R, Gantner D, Irving DO, Kaukonen KM, McArthur C, Murray L, Pettila V, French C (2017) Age of red cells for transfusion and outcomes in critically ill adults. N Engl I Med 377:1858-1867

19. Angus DC, Barnato AE, Bell D, Bellomo R, Chong CR, Coats TJ, Davies A, Delaney A, Harrison DA, Holdgate A, Howe B, Huang DT, Iwashyna T, Kellum JA, Peake SL, Pike F, Reade MC, Rowan KM, Singer M, Webb SAR, Weissfeld LA, Yealy DM, Young JD (2015) A systematic review and meta-analysis of early goal-directed therapy for septic shock: the ARISE, ProCESS and ProMISe Investigators. Intensive Care Med 41:1549-1560

20. Nielsen N, Wetterslev J, Cronberg T, Erlinge D, Gasche Y, Hassager C, Horn J, Hovdenes J, Kjaergaard J, Kuiper M, Pellis T, Stammet P, Wanscher M, Wise MP, Aneman A, Al-Subaie N, Boesgaard S, Bro-Jeppesen J, Brunetti I, Bugge JF, Hingston CD, Juffermans NP, Koopmans M, Køber L, Langørgen J, Lilja G, Møller JE, Rundgren M, Rylander C, Smid O, Werer C, Winkel P, Friberg H (2013) Targeted temperature management at 33 versus $36^{\circ} \mathrm{C}$ after cardiac arrest. N Engl J Med 369:2197-2206 